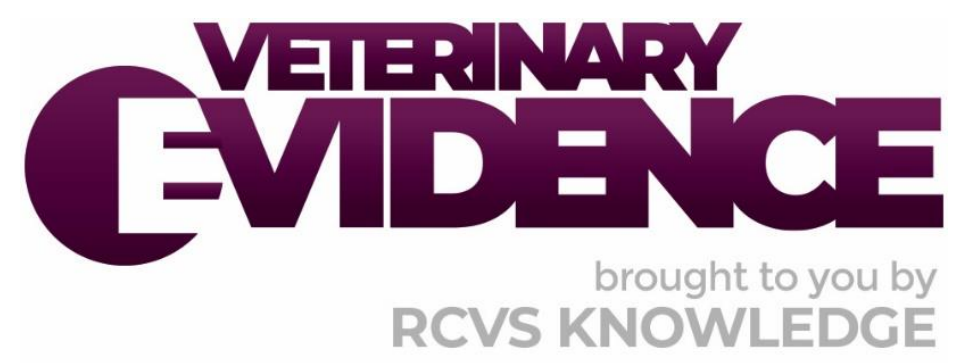

\title{
Choosing Treatment for Dogs With Generalised Demodicosis - Isoxazolines or Imidacloprid and Moxidectin?
}

\author{
A Knowledge Summary by
}

Sarah Long BVSc, CertAVP, MRCVS ${ }^{1 *}$

\footnotetext{
${ }^{1}$ Locum Veterinary Surgeon, United Kingdom

* Corresponding Author (sarahmlong@hotmail.co.uk)
}

ISSN: 2396-9776

Published: 23 Apr 2019

in: Vol 4, Issue 2

DOI: http://dx.doi.org/10.18849/ve.v4i2.183

Reviewed by: Constance White (DVM, PhD) and Roberta Perego (DVM, PhD) 


\section{PICO question}

In dogs with generalised demodicosis, are isoxazolines as effective as a combined formulation of imidacloprid and moxidectin at reducing mite count and the severity of associated clinical signs?

\section{Clinical bottom line}

Five single-blinded, randomised, positive control trials, most under laboratory conditions, directly compared the use of isoxazolines against moxidectin/imidacloprid to treat canine generalised demodicosis. All of them showed comparable efficacy of isoxazolines. Three different isoxazolines were studied with two routes of administration (oral and topical) and four different dosing frequencies of moxidectin/imidacloprid. This made the papers more challenging to compare however, the evidence provided is sufficient to support their use. All of these trials were sponsored by the manufacturers of their respective isoxazoline products which may bias the study design and reporting of results. It is worth noting that sarolaner (Simparica ${ }^{\mathrm{TM}}$, Zoetis UK) was licensed in the UK for the treatment of canine demodicosis in January 2018 and that in the UK the Cascade should be followed when prescribing treatments. The licensed use of isoxazolines in other countries is beyond the scope of this article and the reader is urged to check local regulatory body advice before prescribing the below medications.

\section{Clinical scenario}

A seven-year-old male, neutered, long-haired, cross breed dog presented with a one month history of erythema, patchy alopecia and follicular casts to the feet, hindlimbs and dorsum. He had not been regularly treated with ectoparasiticides and had no previous history of skin disease. Deep skin scrapings from the affected areas revealed two to eight live Demodex canis mites per slide. Cytology showed mild numbers of surface cocci only with no inflammatory cells. His clinical exam was otherwise unremarkable and full blood count, biochemistry and urinalysis were within reference intervals.

\section{The evidence}

A recent systematic review by Perego et al. (2019) found good evidence for the use fluralaner and sarolaner with a good level of efficacy and safety, although long term follow up was lacking. They also found good evidence for the use of moxidectin/imidacloprid and noted improved efficacy with increased frequency of application (Perego et al., 2019). Moxidectin with imidacloprid is a good choice of positive control as it is a commonly used, licensed product for the treatment of canine demodicosis in the UK. Amitraz (Aludex ${ }^{\circledR}$, MSD Animal Health) is also licensed for this purpose in the UK but is less commonly used as it is more difficult to get hold of, is more labour intensive and Perego et al. (2019) found insufficient evidence for its use. There is good evidence for the use of other treatment options that are not licensed in the UK for demodicosis, but may be licensed in other countries, such as milbemycin oxime and doramectin (Perego et al., 2019). Ivermectin has been used with good efficacy however, adverse effects are common and can be severe (Perego et al., 2019). The five papers found were all single-blinded, randomised positive control trials with four performed under laboratory conditions. They all directly compared isoxazoline ectoparasiticides to moxidectin combined with imidacloprid. Whilst the studies were small and their power was not calculated, they provide good evidence for the comparable efficacy of isoxazolines as a treatment for canine generalised demodicosis (Perego et al., 2019). None of these studies calculated confidence intervals and this would have strengthened the evidence 
they provide. Four of the five were also performed under laboratory conditions which may not represent conditions in the general population.

\section{Summary of the evidence}

Becskei, C., Cuppens, O. and Mahabir, S. P. (2018)

\begin{tabular}{|c|c|}
\hline Population: & $\begin{array}{l}\text { Client owned dogs with clinical signs of generalised demodicosis that } \\
\text { showed: } \\
\text { - Skin lesions on at least five body regions, entire body or } \\
\text { pododemodicosis } \\
\text { - At least four live Demodex canis mites found on skin } \\
\text { scrapings } \\
\text { Patients were excluded if they were pregnant, lactating, intended } \\
\text { for breeding, receiving immunosuppressive therapy, receiving } \\
\text { systemic or topical antimicrobials, had been treated with an } \\
\text { ectoparasiticide with residual activity against Demodex canis, had } \\
\text { Sarcoptes scabiei mites or were under } 8 \text { weeks of age. The study } \\
\text { population was recruited from centres in France, Hungary, Portugal } \\
\text { and Italy. }\end{array}$ \\
\hline Sample size: & 81 dogs \\
\hline Intervention details: & $\begin{array}{l}\text { - } \quad \text { Patients were split into two groups in a ratio of 2:1 } \\
\text { - } 53 \text { dogs received sarolaner, } 28 \text { moxidectin/imidacloprid } \\
\text { - } \text { multiple clinics } \\
\text { - } 53 \text { dogs received sarolaner per os at } 2-4 \mathrm{mg} / \mathrm{kg} \text { on days } 0,30 \\
\text { and if necessary } 60,90,120 \text { and } 150 \\
\text { - } 28 \text { dogs received a topical application of moxidectin } \\
\text { combined with imidacloprid at a minimum dose of } 10 \mathrm{mg} / \mathrm{kg} \\
\text { and } 2.5 \mathrm{mg} / \mathrm{kg} \text { respectively given monthly, or weekly in } \\
\text { severe cases } \\
\text { The severity of demodicosis was evaluated at every monthly } \\
\text { visit }\end{array}$ \\
\hline Study design: & Single-blinded, randomised non-inferiority trial \\
\hline Outcome studied: & $\begin{array}{l}\text { The non-inferiority of sarolaner compared to } \\
\text { moxidectin/imidacloprid } \\
\text { Objective - number of live Demodex canis mites found in five deep } \\
\text { skin scrapes taken from the same sites } \\
\text { - The sites were selected based on clinical exam. Areas that } \\
\text { had primary lesions and showed the most severe evidence of } \\
\text { current mite infestation were chosen } \\
\text { - Approximately } 1 \mathrm{~cm}^{2} \text { of skin was sampled at each site } \\
\text { - A one-sided } 97.5 \% \text { exact lower confidence limit for the } \\
\text { difference between cure rates for each treatment group was } \\
\text { used to assess non-inferiority of sarolaner at the } 0.025 \text { one- } \\
\text { sided significance level at days } 30 \text { and } 60\end{array}$ \\
\hline
\end{tabular}




\begin{tabular}{|c|c|}
\hline & $\begin{array}{l}\text { - A non-inferiority margin of } 15 \% \text { was used } \\
\text { Subjective - the severity of clinical signs was graded } \\
\text { - } \quad \text { Absent } \\
\text { - } \quad \text { Mild (small body area affected, low intensity) } \\
\text { - Moderate (great intensity and density of lesions over a small } \\
\text { area) } \\
\text { - Severe (great intensity and density of lesions over a large } \\
\text { area) }\end{array}$ \\
\hline $\begin{array}{l}\text { Main findings: } \\
\text { (relevant to PICO question): }\end{array}$ & $\begin{array}{l}\text { The parasitological cure rate for sarolaner was non-inferior } \\
\text { to moxidectin/imidacloprid on day } 60 \text { but not day } 30 \text { (based } \\
\text { on a present non-inferiority margin of } 15 \% \text { ) } \\
\text { - } \quad \text { There was no significant difference between cure rates for } \\
\text { treatment groups on days } 30 \text { or } 60 \\
\text { - } 100 \% \text { of dogs receiving sarolaner that completed the study } \\
(53 / 53 \text { ) achieved parasitological cure } \\
\text { - } 88.9 \% \text { of the moxidectin/imidacloprid dogs that completed } \\
\text { the study ( } 24 / 27 \text { ) achieved parasitological cure, one dog was } \\
\text { withdrawn due to lack of efficacy at day } 146 \\
\text { - The percentage reduction in mean mite counts for sarolaner } \\
\text { was non-inferior to moxidectin/imidacloprid at days } 30 \text { and } \\
60 \\
\text { At day } 90 \text { (when approximately } 80 \% \text { of each group was still } \\
\text { analysed) the total body area affected was } 5 \% \text { in the } \\
\text { sarolaner group and } 10 \% \text { in the moxidectin/imidacloprid } \\
\text { group } \\
\text { No adverse events were associated with either treatment }\end{array}$ \\
\hline Limitations: & $\begin{array}{l}\text { Two of the dogs in the sarolaner group received systemic } \\
\text { antibiotics during the trial and this may have hastened the } \\
\text { improvement in their skin lesions, the authors do } \\
\text { acknowledge this } \\
\text { - Moxidectin/imidacloprid is licensed to apply once monthly } \\
\text { although the data sheet notes (Advocate }{ }^{\mathrm{T} M} \text { Spot-on solution, } \\
\text { Bayer PLC, as published in the National Office of Animal } \\
\text { Health (NOAH) Compendium 2019) that, at the case vet's } \\
\text { discretion, it can be applied weekly to treat demodicosis } \\
\text { - Weekly treatments were administered at home by the } \\
\text { owner, this may have led to variability in the dose received } \\
\text { by the patient due to accuracy of application } \\
\text { Dogs in the moxidectin/imidacloprid group had different } \\
\text { dosing intervals based on the severity of their condition, this } \\
\text { may have added variance to the results } \\
\text { The authors state that sarolaner appears to be at least as } \\
\text { good as or better than most other miticides however, their } \\
\text { study only proves non-inferiority not that sarolaner is a } \\
\text { superior treatment }\end{array}$ \\
\hline
\end{tabular}




\begin{tabular}{|c|c|}
\hline & $\begin{array}{l}\text { - Ideally investigations for underlying disease should have } \\
\text { been performed prior to enrolment e.g. blood and urine } \\
\text { tests } \\
\text { - Information regarding the age, breed and other baseline } \\
\text { characteristics for each animal was not provided other than that } \\
\text { they were over } 8 \text { weeks } \\
\text { - } \quad \text { There is no calculation of the power of the study or } \\
\text { explanation why a ratio of 2:1 was chosen } \\
\text { - Confidence intervals are not calculated } \\
\text { - No justification for using mean rather than median age } \\
\text { - It is unclear if animals were assessed by one or multiple } \\
\text { assessors } \\
\text { - All the authors were employees of Zoetis UK who } \\
\text { manufacture sarolaner (Simparica }\end{array}$ \\
\hline
\end{tabular}

Six R. H. et al. (2016)

\begin{tabular}{|c|c|}
\hline Population: & $\begin{array}{l}\text { Dogs with naturally occurring Demodex canis infestations that } \\
\text { showed clinical signs of generalised demodicosis (alopecia, } \\
\text { erythema, comedones, papules and pustules, casts, scales or crusts } \\
\text { that involved five or more body regions or pododemodicosis). } \\
\text { - At least four live Demodex canis mites seen on deep skin } \\
\text { scrapings } \\
\text { - Dogs were not treated with an ectoparasiticide for at least } \\
\text { - They days prior to the study } \\
\text { - Theek prior or a long acting corticosteroid for } 4 \text { weeks prior } \\
\text { - The dogs were recruited from South Africa, they were } \\
\text { 'locally sourced' mongrels over } 6 \text { months of age }\end{array}$ \\
\hline Sample size: & 16 dogs \\
\hline Intervention details: & $\begin{array}{l}\text { - } \quad \text { Dogs were housed individually } \\
\text { - } 8 \text { dogs were allocated to each group } \\
\text { - } \quad \text { Dogs were fed a commercial dry food for the duration of the } \\
\text { study and given water ad lib } \\
\text { - } \quad \text { Dogs were acclimatised to the study conditions for at least } \\
14 \text { days before the first treatment was administered } \\
\text { - } \quad \text { Dogs were randomly allocated by ranking of mite count } \\
\text { - } \quad \text { Sarolaner was given per os at a dose rate of } 2 \mathrm{mg} / \mathrm{kg} \text { (tablets } \\
\text { were shaved/sanded to aid accurate dosing) on days } 0,30 \\
\text { and } 60 \\
\text { - Moxidectin/imidacloprid was applied topically at a minimum } \\
\text { of } 10 \mathrm{mg} / \mathrm{kg} \text { and } 2.5 \mathrm{mg} / \mathrm{kg} \text { respectively given once weekly } \\
\text { from day } 0-81 \\
\text { - Deep skin scrapings were taken from five sites showing the } \\
\text { most severe clinical signs based on visual examination }\end{array}$ \\
\hline
\end{tabular}




\begin{tabular}{|c|c|}
\hline & $\begin{array}{l}\text { - The same sites were scraped each time } \\
\text { - Clinical signs were assessed through surface area affected } \\
\text { by: comedones/pustules/papules, casts/crusts/scales, } \\
\text { alopecia and erythema } \\
\text { - Examination and skin scraping was performed on days } 14, \\
\text { 29, 44, 59, } 74 \text { and } 91 \\
\text { - The assessors were blinded to treatment group }\end{array}$ \\
\hline Study design: & $\begin{array}{l}\text { Single-blinded, randomised positive control trial under laboratory } \\
\text { conditions (it is not stated if this is a superiority or non-inferiority } \\
\text { trial) }\end{array}$ \\
\hline Outcome studied: & $\begin{array}{l}\text { Objective - live mite counts } \\
\text { - } \text { Mite counts were transformed by } \log _{\mathrm{e}}(\mathrm{count}+1) \text { prior to } \\
\text { analysis to remove excessive variance } \\
\text { - } \text { Differences were assessed at the two-sided significance level } \\
\alpha=0.05 \\
\text { - } \quad \text { Geometric means were calculated from the least square } \\
\text { means and used to minimise extreme outliers } \\
\text { - One dog was excluded from the moxidectin/imidacloprid } \\
\text { group due to an accidental laceration requiring antibiotic } \\
\text { treatment }\end{array}$ \\
\hline $\begin{array}{l}\text { Main findings: } \\
\text { (relevant to PICO question): }\end{array}$ & $\begin{array}{l}\text { - Both treatments reduced live mite counts post-treatment } \\
\text { compared to pre-treatment counts }(P<0.0001) \\
\text { - This was more rapid for the sarolaner group with a } \\
\text { significant difference at day } 14 \text { ( } P=0.0331) \text { and day } 29 \text { ( } P= \\
\text { 0.0038) compared to the moxidectin/imidacloprid group } \\
\text { - } \quad \text { Mean counts were not significantly different after this } \\
\text { - } \quad \text { At day } 44100 \% \text { of sarolaner treated dogs had negative } \\
\text { scrapes } \\
\text { - } \quad \text { At day } 59100 \% \text { of moxidectin/imidacloprid treated dogs had } \\
\text { negative scrapes } \\
\text { - Comedones, papules and pustules had resolved by day } 29 \text { in } \\
\text { both groups } \\
\text { - Casts, crusts and scales had resolved in seven dogs in each } \\
\text { group by study completion } \\
\text { One sarolaner and two moxidectin/imidacloprid treated } \\
\text { dogs still showed erythema and alopecia at the end of the } \\
\text { trial } \\
\text { Total area affected by lesions reduced from } 65 \% \\
\text { pretreatment to } 1-2 \% \text { at study completion } \\
\text { No adverse events were associated with either treatment }\end{array}$ \\
\hline Limitations: & $\begin{array}{l}\text { - Information regarding the age, breed and other baseline } \\
\text { characteristics for each animal was not provided } \\
\text { - It was not explained how the surface area affected was } \\
\text { calculated }\end{array}$ \\
\hline
\end{tabular}




\begin{tabular}{|c|c|c|}
\hline & & $\begin{array}{l}\text { Dogs were examined clinically and considered in good health } \\
\text { but there is no information as to how this was established } \\
\text { e.g. were blood or urine tests performed to rule out } \\
\text { underlying disease } \\
\text { Dogs were kept under laboratory conditions which may not } \\
\text { be representative of a clinical scenario } \\
\text { The sample size is small, there is no calculation of power or } \\
\text { how the sample size was reached, this may have affected } \\
\text { the outcome } \\
\text { Confidence intervals are not calculated } \\
\text { It is unclear where these dogs came from raising ethical } \\
\text { concerns enrolling them in the study as there is no mention } \\
\text { of owner consent, if there was any financial gain or if they } \\
\text { are strays } \\
\text { It is not clear how dogs were randomly allocated to the two } \\
\text { treatment groups or if they were evenly distributed based } \\
\text { on mite count } \\
\text { All of the authors were employees, directly or indirectly of } \\
\text { Zoetis UK who manufacture sarolaner (SimparicaTM) } \\
\text { Another arm of this study involved infecting purpose bred } \\
\text { laboratory Beagles with Otodectes cynotis and the control } \\
\text { group were given a placebo treatment which represents a } \\
\text { potential welfare issue for these dogs }\end{array}$ \\
\hline
\end{tabular}

Fourie J. J. et al. (2015)

\begin{tabular}{|c|c|}
\hline Population: & $\begin{array}{l}\text { Client owned dogs with naturally occurring generalised demodicosis } \\
\text { that showed clinical signs (erythema, alopecia, comedones, follicular } \\
\text { casts and crusts) and Demodex canis mites found on deep skin } \\
\text { scrapings. Patients were otherwise healthy and had not been treated } \\
\text { with a glucocorticoid or miticide for at least } 12 \text { weeks prior to the } \\
\text { study. The study was conducted in South Africa. }\end{array}$ \\
\hline Sample size: & 16 dogs \\
\hline Intervention details: & $\begin{array}{l}\text { - Dogs were housed separately during the study period and } \\
\text { - } 8 \text { dogs were allocated to each treatment group } \\
\text { - } \quad \text { Dogs were acclimatised to their new housing for at least } 14 \\
\text { days before the study commenced } \\
\text { - } \quad \text { All dogs were treated with a subcutaneous injection of } \\
\text { cefovecin on days }-14,-1,13 \text { and } 27 \text { for the treatment of } \\
\text { pyoderma } \\
\text { - Deep skin biopsies were taken from all dogs on days - } 14 \text { and } \\
27 \\
\text { - Group } 1 \text { were treated with fluralaner at a minimum dose of } \\
24 \mathrm{mg} / \mathrm{kg} \text { on day } 0\end{array}$ \\
\hline
\end{tabular}




\begin{tabular}{|c|c|}
\hline & $\begin{array}{l}\text { - Group } 2 \text { were treated with } 2.5 \mathrm{mg} / \mathrm{kg} \text { moxidectin } / 10 \mathrm{mg} / \mathrm{kg} \\
\text { imidacloprid topically according to the manufacturer's } \\
\text { guidelines on days } 0,28 \text { and } 56 \\
\text { - Deep skin scrapings were taken from an area approximately } \\
4 \mathrm{~cm}^{2} \text { from five sites on days }-4,28,56 \text { and } 84 \text { and the same } \\
\text { sites were sampled each time } \\
\text { - Clinical signs were assessed on days }-4,28,56 \text { and } 84, \text { the } \\
\text { body areas affected were sketched on a silhouette } \\
\text { - Lesions recorded: erythema, casts, scales, crusts, alopecia } \\
\text { - Percentage of hair regrowth was estimated } \\
\text { - Colour photographs were taken to help compare lesions at } \\
\text { each assessment }\end{array}$ \\
\hline Study design: & $\begin{array}{l}\text { Single-blinded randomised positive control trial under laboratory } \\
\text { conditions (it is not stated if this is a superiority or non-inferiority } \\
\text { trial) }\end{array}$ \\
\hline Outcome studied: & $\begin{array}{l}\text { Objective - mean mite number on skin scrapings } \\
\text { - Efficacy was calculated using geometric means and Abbot's } \\
\text { formula } \\
\text { - The groups were compared using an analysis of variance test } \\
\text { (ANOVA) with a treatment effect after a logarithmic } \\
\text { transformation of the mite (count }+1 \text { ) data for each study } \\
\text { day } \\
\text { Subjective - improvement in clinical signs }\end{array}$ \\
\hline $\begin{array}{l}\text { Main findings: } \\
\text { (relevant to PICO question): }\end{array}$ & 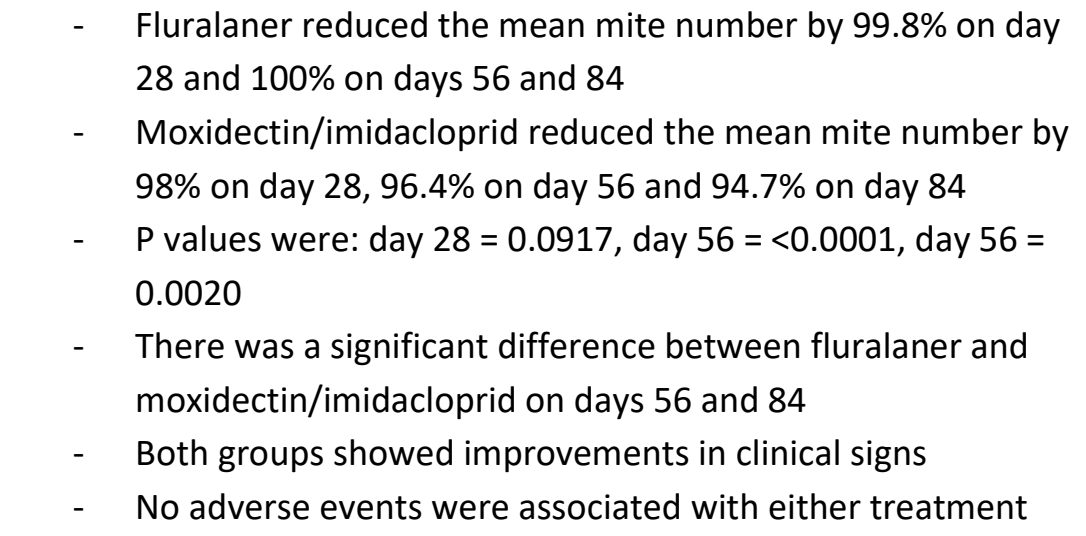 \\
\hline Limitations: & $\begin{array}{l}\text { Moxidectin/imidacloprid was used at the licensed dosing } \\
\text { interval however, the data sheet (Advocate }{ }^{\mathrm{TM}} \text { Spot-on } \\
\text { solution, Bayer PLC, as published in NOAH Compendium } \\
\text { 2019) states that for the treatment of demodicosis it can be } \\
\text { used weekly at the case vet's discretion. This may have } \\
\text { affected the treatment response in this study } \\
\text { - There is limited information regarding the statistical analysis } \\
\text { of the data (e.g. statistical package used, ANOVA } \\
\text { assumptions) and only geometric mean mite counts were } \\
\text { provided } \\
\text { Information regarding the age, breed and other baseline } \\
\text { characteristics for each animal were not provided }\end{array}$ \\
\hline
\end{tabular}




\begin{tabular}{|c|c|}
\hline & $\begin{array}{l}\text { - Dogs were kept under laboratory conditions which may not } \\
\text { be representative of a clinical scenario } \\
\text { - The authors state the dogs were 'healthy as far as could be } \\
\text { determined' but do not clarify what tests were performed } \\
\text { - One of the dogs was withdrawn from the } \\
\text { moxidectin/imidacloprid group on day } 59 \text { due to the } \\
\text { development of malignant lymphoma but the data before } \\
\text { this date was included in the trial. This may have affected } \\
\text { the treatment response for this group } \\
\text { - Ideally antibiotics should have been used based on skin } \\
\text { cytology and presence of pyoderma, presumably blanket } \\
\text { treatment was chosen to avoid variance } \\
\text { - A sample size of } 16 \text { dogs is small and there is no justification } \\
\text { of this or calculation of the power of the study. This may } \\
\text { have affected the results } \\
\text { - Confidence intervals were not calculated } \\
\text { - There was no information on recruitment measures (e.g. } \\
\text { financial incentives) or source of cases } \\
\text { - Five of the six authors were employees, directly or indirectly } \\
\text { of MSD Animal Health the manufacturers of fluralaner } \\
\text { (Bravecto }{ }^{\circledR} \text { ) }\end{array}$ \\
\hline
\end{tabular}

\begin{tabular}{|c|c|}
\hline \multicolumn{2}{|l|}{ Beugnet, F. et al. (2016) } \\
\hline \multirow[t]{2}{*}{ Population: } & $\begin{array}{l}\text { Client owned dogs over } 6 \text { months of age that showed signs of } \\
\text { generalised demodicosis on days }-14,-7 \text {, and }-2 \text { or }-1 \text {. All dogs } \\
\text { showed lesions (erythema, crusts, scales, alopecia, comedones or } \\
\text { follicular casts) on either at least five body regions, an entire body } \\
\text { region or two or more feet. All dogs had Demodex canis mites } \\
\text { confirmed on deep skin scrapings on day }-1 \text {. None of the dogs were } \\
\text { pregnant or had been treated with a glucocorticoid or } \\
\text { ectoparasiticide for } 12 \text { weeks prior to the study. Antibiotics and } \\
\text { vitamin/mineral supplements were allowed during the trial. Dogs } \\
\text { were leased from their owners and recruited from South Africa. }\end{array}$ \\
\hline & 16 dogs split \\
\hline Intervention details: & $\begin{array}{l}\text { Dogs were randomised into treatment groups by ranking of } \\
\text { pre-treatment mite counts and sex and } 8 \text { dogs allocated to } \\
\text { each group } \\
\text { - Dogs were housed in separate pens, fed once daily and } \\
\text { water was given ad lib. They were moved to this housing for } \\
\text { at least } 14 \text { days prior to the start of the study } \\
\text { - Group } 1 \text { received afoxolaner and group } 2 \\
\text { moxidectin/imidacloprid both dosed according to the } \\
\text { manufacturer's guidelines. No further information on dosing } \\
\text { was provided }\end{array}$ \\
\hline
\end{tabular}




\begin{tabular}{|c|c|}
\hline & 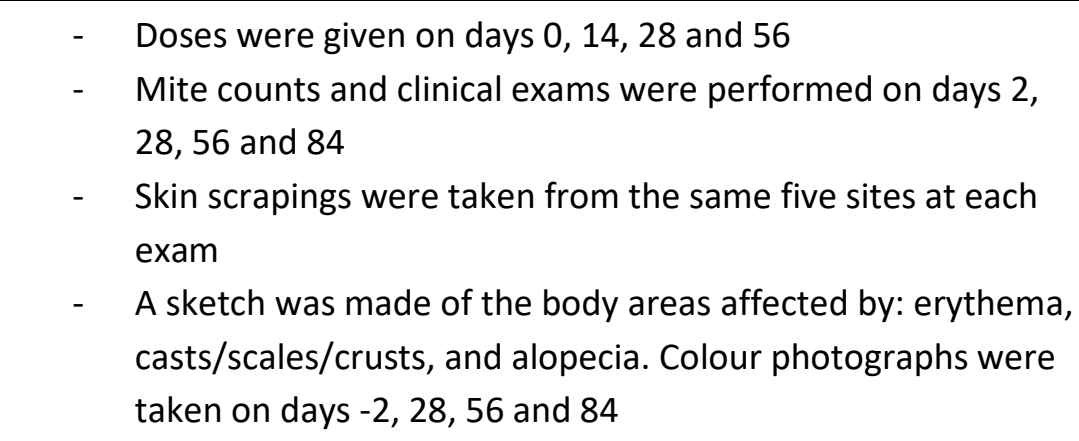 \\
\hline Study design: & $\begin{array}{l}\text { Single-blinded, randomised positive control trial under laboratory } \\
\text { conditions (it is not stated if this is a superiority or non-inferiority } \\
\text { trial) }\end{array}$ \\
\hline Outcome studied: & $\begin{array}{l}\text { Objective - mean mite counts } \\
\text { - The group mean, median, standard deviation, geometric } \\
\text { mean, minimum and maximum counts were calculated } \\
\text { - Pre and post-treatment administration mite counts were } \\
\text { compared using ANOVA and a significance level of } 5 \% \text { was } \\
\text { set } \\
\text { Subjective - clinical lesions and hair regrowth }\end{array}$ \\
\hline $\begin{array}{l}\text { Main findings: } \\
\text { (relevant to PICO question): }\end{array}$ & $\begin{array}{l}\text { - There was a significant }(\mathrm{P}<0.05) \text { reduction in mite count for } \\
\text { both groups on all post-treatment assessments } \\
\text { - } \quad \text { Group } 1 \text { (moxidectin/imidacloprid) mite count reduced from } \\
\text { a geometric mean of } 808.1 \text { before treatment to } 82.4-119.9 \\
\text { after one month } \\
\text { - } \quad \text { Group } 2 \text { (afoxolaner) mite count reduced from a geometric } \\
\text { mean of } 650.8 \text { before treatment to } 0.0-5.3 \text { after one month } \\
\text { - } \quad \text { There was no significant difference in mean mite count }(P= \\
\text { 0.8103) between the groups at the start of the trial } \\
\text { - } \quad \text { Significantly fewer mites were found on all post-treatment } \\
\text { assessments for the afoxolaner group compared to the } \\
\text { moxidectin/imidacloprid group ( } P<0.05 \text { ) } \\
\text { - Both groups showed improvements in clinical signs but no } \\
\text { resolution of them } \\
\text { No adverse events were associated with either treatment }\end{array}$ \\
\hline Limitations: & $\begin{array}{l}\text { The dosing interval of moxidectin/imidacloprid was every } 2 \\
\text { weeks for three doses then every } 4 \text { weeks. The authors } \\
\text { acknowledge that weekly treatment, as suggested in the } \\
\text { manufacturer's guidelines, may have improved treatment } \\
\text { outcome but do not state why they chose not to treat at this } \\
\text { interval } \\
\text { - The authors chose eight dogs per group as it was higher } \\
\text { than the six recommended by the Committee for Medical } \\
\text { Products for Veterinary Use guideline but do not calculate } \\
\text { the power of the study } \\
\text { Confidence intervals were not calculated }\end{array}$ \\
\hline
\end{tabular}




\begin{tabular}{|c|c|}
\hline & $\begin{array}{l}\text { - Limited information is provided on statistical analysis e.g. } \\
\text { ANOVA assumptions } \\
\text { - Dogs were leased from their owners indicating a financial } \\
\text { gain and potential ethical implications } \\
\text { - } \quad \text { Afoxolaner was used off license at } 2 \text { weekly intervals, they } \\
\text { acknowledge that further study of monthly administration is } \\
\text { warranted } \\
\text { - The dogs were split into blocks of two based on sex and } \\
\text { mean mite count, it is not clear if they were then randomly } \\
\text { allocated to the two treatment groups or evenly distributed } \\
\text { based on mite count } \\
\text { - Dogs were kept under laboratory conditions which may not } \\
\text { be representative of a clinical scenario } \\
\text { - Information regarding the age, breed and other baseline } \\
\text { characteristics for each animal is not provided } \\
\text { - All of the authors were employees, directly or indirectly of } \\
\text { Merial the manufacturer of Afoxolaner (NexGard }{ }^{\circledR} \text { ) }\end{array}$ \\
\hline
\end{tabular}

Fourie, J. J., Meyer, L. and Thomas, E. (2019)

\begin{tabular}{|c|c|}
\hline Population: & 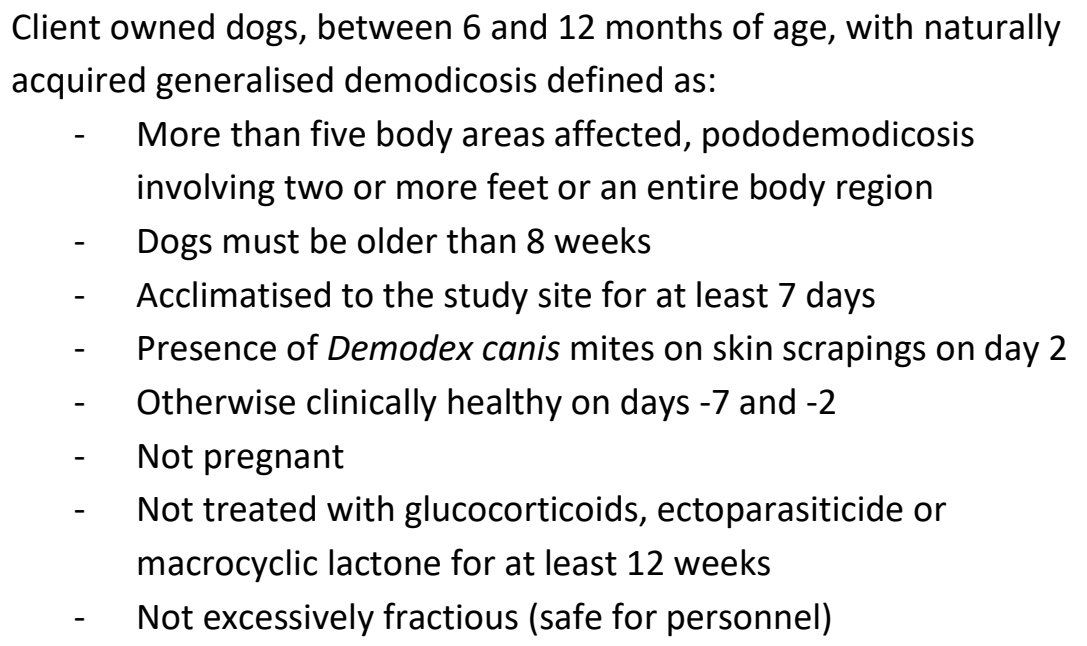 \\
\hline Sample size: & 16 dogs \\
\hline Intervention details: & $\begin{array}{l}\text { - Dogs were ranked by mite count then randomly allocated to } \\
1 \text { of } 2 \text { groups using MS Excel software, } 8 \text { dogs were allocated } \\
\text { to each group } \\
\text { - } \quad \text { Age was assessed based on presence of permanent dentition } \\
\text { - } \quad \text { Dogs were transferred to the study site and housed } \\
\text { individually indoors } \\
\text { - } \quad \text { Dogs were fed a commercially available dry dog food once } \\
\text { daily with water ad lib } \\
\text { - } \quad \text { Group 1: } 25 \mathrm{mg} / \mathrm{kg} \text { fluralaner applied topically on day } 0 \\
\text { - Group 2: At least } 10 \mathrm{mg} / \mathrm{kg} \text { imidacloprid and } 2.5 \mathrm{mg} / \mathrm{kg} \\
\text { - } \text { moxidectin applied topically on days } 0,28 \text { and } 56 \\
\text { Four dogs in Group } 2 \text { were treated weekly rather than every }\end{array}$ \\
\hline
\end{tabular}




\begin{tabular}{|c|c|}
\hline & $\begin{array}{l}4 \text { weeks (based on manufacturer's guidelines) } \\
\text { - Cases classified as mild, moderate or severe based on clinical } \\
\text { condition (crusts, casts, scales, hair loss and erythematous } \\
\text { papules) by blinded veterinarian and examinations } \\
\text { performed every } 2 \text { weeks } \\
\text { - } \quad \text { All dogs were treated with cefovecin (Convenia }{ }^{\circledR} \text { ) for } \\
\text { potential pyoderma on days }-7,7,21,35 \text { and } 49 \text { and a } \\
\text { probioitic (Protexin }{ }^{\circledR} \text { ) at least twice weekly } \\
\text { - Skin biopsies were performed on days - } 7 \text { and } 27 \text { to assess for } \\
\text { Demodex canis mites, acanthosis, hyperkeratosis, surface } \\
\text { crusting, pigmentary incontinence, follicular keratosis, mural } \\
\text { folliculitis, perifolliculitis, dermatitis, bacteria, granulomas } \\
\text { and dermal stromal reaction } \\
\text { Skin scrapings and mite counts were performed on days -2, } \\
28,56 \text { and } 84 \text { and were blinded } \\
\text { - Deep skin scrapings were taken from an area approximately } \\
4 \mathrm{~cm}^{2} \text { at the same five sites for each dog on every occasion } \\
\text { Only live mites were recorded }\end{array}$ \\
\hline Study design: & $\begin{array}{l}\text { Single-blinded, randomised, non-inferiority trial under laboratory } \\
\text { conditions }\end{array}$ \\
\hline Outcome studied: & 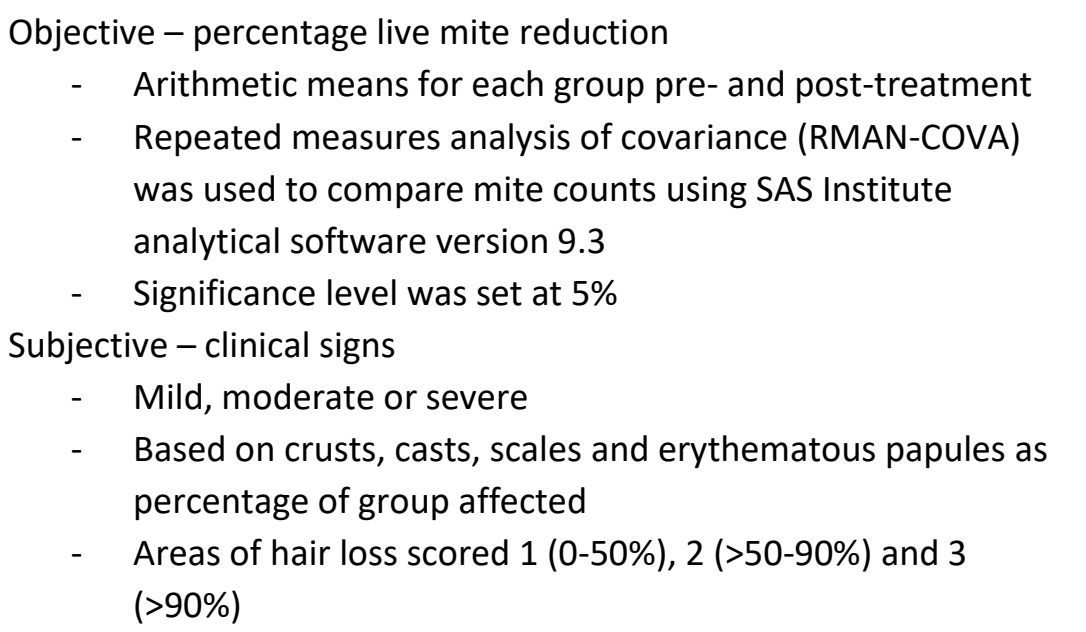 \\
\hline $\begin{array}{l}\text { Main findings: } \\
\text { (relevant to PICO question): }\end{array}$ & $\begin{array}{l}\text { - } \quad \text { No treatment related adverse events were noted } \\
\text { - } \text { moxalaner was significantly more effective than } \\
\text { with generalised demodicosis }(\mathrm{P}<0.01) \\
\text { - } \quad 0 / 8 \text { dogs in group } 1 \text { had any live mites at day } 84 \\
\text { - } \quad 1 / 8 \text { dogs in group } 2 \text { was mite free at day } 56 \text { and } 2 / 8 \text { at day } \\
84 \\
\text { - } \quad 2 / 8 \text { dogs in group } 2 \text { showed an increase in live mite counts } \\
\text { after treatment and this impacted significantly on efficacy } \\
\text { calculations (based on mean mite counts for the group) }\end{array}$ \\
\hline Limitations: & $\begin{array}{l}\text { - Group } 2 \text { dogs received two different treatment regimes } \\
\text { (weekly and four weekly application) but results were not }\end{array}$ \\
\hline
\end{tabular}




\begin{tabular}{|c|c|c|}
\hline & & $\begin{array}{l}\text { analysed separately } \\
\text { All dogs were given } 10 \text { weeks of cefovecin regardless of the } \\
\text { presence or absence of pyoderma, the authors note that } \\
\text { diagnosis and treatment of pyoderma was not part of the } \\
\text { treatment evaluation } \\
\text { Dogs were between } 6 \text { and } 12 \text { months of age indicating } \\
\text { juvenile generalised demodicosis rather than adult onset } \\
\text { which has the potential for self-resolution of signs, this may } \\
\text { have affected results } \\
\text { The age, sex and breed of dogs in each group is not recorded } \\
\text { Dogs were ranked by mite count before being randomly } \\
\text { allocated to treatment groups but the reason for ranking } \\
\text { before randomisation is not clear } \\
\text { Dogs were kept under laboratory conditions which may not } \\
\text { be representative of a clinical scenario } \\
\text { Ideally antibiotics should have been used based on skin } \\
\text { cytology and presence of pyoderma, presumably blanket } \\
\text { treatment was chosen to avoid variance } \\
\text { A sample size of } 16 \text { is small and there is no justification for } \\
\text { this or calculation of the power of the study. This may have } \\
\text { affected the results } \\
\text { Confidence intervals were not calculated } \\
\text { No criteria for treatment success were outlined and results } \\
\text { were only provided for live mite counts (not clinical signs or } \\
\text { histopathology) } \\
\text { No information on recruitment measures (e.g. financial } \\
\text { incentives) or source of cases } \\
\text { It is unclear what the aim of the study was, the authors state } \\
\text { 'to evaluate the efficacy... compared to } \\
\text { moxidectin/imidacloprid' but not if this is an inferiority or } \\
\text { superiority study however, the authors then state } \\
\text { superiority in the results and discussion } \\
\text { All authors were employed (directly or indirectly) by MSD } \\
\text { Summal Health, the manufacturer of fluralaner (Bravecto }{ }^{\circledR} \text { ) } \\
\text { PLC) referenced are for cats and ferrets, not dogs }\end{array}$ \\
\hline
\end{tabular}

\section{Appraisal, application and reflection}

Three different, widely available, isoxazolines were studied in these five papers, two focused on sarolaner, two on fluralaner and one on afoxolaner. All five studies were sponsored by the pharmaceutical companies that make the isoxazoline preparations and nearly all authors were employees of these companies. This may bias study design and reporting of results as demonstrated in the study by Becskei et al. (2018) where sarolaner is claimed to be as good as, if not better than moxidectin/imidacloprid, but the study was only 
designed to prove non-inferiority. In each paper the dosing frequency of moxidectin/imidacloprid varied making them harder to compare. The license for this product is for monthly application, however, the data sheet (Advocate ${ }^{\mathrm{TM}}$ Spot-on solution, Bayer PLC, as published in NOAH Compendium 2019) states that it can be used weekly to treat canine demodicosis in more severe cases at the case veterinarian's discretion. Ideally all papers would have used weekly dosing intervals as this is more effective (Mueller et al., 2012, Perego et al., 2019). Monthly treatments may have only been successful in mild cases and this may be why Fourie et al. (2015) found such a significant difference between the two treatment groups.

Generalised adult onset demodicosis can be associated with immunosuppression. The cause of this may be difficult to identify but ideally a full blood count, biochemistry, urinalysis, lymph node aspirates, thoracic radiographs and abdominal ultrasound should be performed to rule out underlying conditions (Mueller et al., 2012). Hyperadrenocorticism and hypothyroidism are important disorders to investigate as part of this process (Mueller et al., 2012). The presence of an underlying condition could alter the treatment response and investigations should have been fully detailed or performed more thoroughly in these papers.

All of the papers show that isoxazolines are at least as effective as moxidectin/imidacloprid at reducing the mean mite count from deep skin scrapings. Deep skin scrapings are the gold standard diagnostic method to identify demodicosis and the area covered should be approximately $1 \mathrm{~cm}^{2}$ and focused on primary lesions (Mueller et al., 2012). At least three to five areas should be sampled and this should be repeated until there are two consecutive negative scrapes one month apart (Mueller et al., 2012). Cytology should also be performed to identify the presence of pyoderma, a common complication of demodicosis (Mueller et al., 2012). Fourie et al. (2015) and Fourie, Meyer and Thomas (2019) treated all dogs with 8 weeks and 10 weeks respectively of a third-generation cefalosporin during the trial. This standardised treatment, but blanket antibiotic usage in these cases, would not be an advisable approach in practice. Identification of pyoderma on cytology and ideally of the bacteria involved through culture and sensitivity is recommended. Fourie, Meyer and Thomas (2019) took skin biopsies to assess for pyoderma however, they do not comment on the findings and note that it took 22 days for biopsy results to be available. As mentioned above, cytological evaluation and culture and sensitivity would have been a preferable method to assess for the presence of pyoderma.

All of these studies use relatively small numbers of patients and four of the five kept animals under laboratory conditions that are unlikely to replicate those of our patients. Confidence intervals are not calculated and some papers lack full detail regarding statistical analysis. Addressing all of these points may increase the strength of evidence provided. Another concern is the use of stray dogs and financial incentives to owners to enroll pets onto the treatment trials. This may compromise animal welfare through separation from owners, normal environments and routines. The Six et al. (2016) study also looked at the efficacy of sarolaner to treat artificial Otodectes cynotisinfestations in laboratory Beagles. The control group in this arm of the trial was given a placebo treatment which again may compromise welfare.

A recent systematic review by Perego et al. (2019) found good evidence for the use of fluralaner and sarolaner in the treatment of generalised demodicosis. Afoxolaner showed good efficacy but only one study was found providing limited evidence for their use. Isoxazolines appear safe as well as efficacious, no adverse effects were noted in any of the studies reviewed here, but further long term follow up is required to confirm this.

\section{Methodology Section}

\begin{tabular}{|c|c|}
\hline $\begin{array}{r}\text { Databases searched and dates } \\
\text { covered: }\end{array}$ & $\begin{array}{l}\text { CAB Abstracts through CAB direct platform } 1973-\text { w } \\
\text { PubMed through NCBI } 1900 \text { - week } 92019 \\
\text { Web of Science } 1900 \text { - week } 92019 \\
\text { Scopus } 1970 \text { - week } 92019\end{array}$ \\
\hline Search terms: & $\begin{array}{l}\text { Dog or dogs or canine* or bitch* or bitches or canis } \\
\text { AND } \\
\text { Demodicosis or demodex or demodectic }\end{array}$ \\
\hline
\end{tabular}


AND

Isoxazoline or isoxazolines or fluralaner or sarolaner or afoxolaner or lotilaner

AND

Imidacloprid or moxidectin or advocate or advantage multi

Dates searches performed: March $1^{\text {st }} 2019$

\section{Exclusion / Inclusion Criteria}

Exclusion: Articles not available in English, narrative reviews, non-peer reviewed journals, book chapters, conference proceedings and articles that did not answer the PICO question

Inclusion: Original, peer reviewed articles that compared isoxazolines with moxidectin/imidacloprid

\begin{tabular}{|c|c|c|c|c|c|}
\hline \multicolumn{6}{|l|}{ Search Outcome } \\
\hline Database & $\begin{array}{c}\text { Number of } \\
\text { results }\end{array}$ & $\begin{array}{c}\text { Excluded - } \\
\text { Review } \\
\text { Articles }\end{array}$ & $\begin{array}{c}\text { Excluded - Did } \\
\text { not answer } \\
\text { the PICO } \\
\text { question }\end{array}$ & $\begin{array}{c}\text { Excluded - Not } \\
\text { available in } \\
\text { English }\end{array}$ & $\begin{array}{c}\text { Total relevant } \\
\text { papers }\end{array}$ \\
\hline CAB Abstracts & 3 & 2 & 0 & 0 & 1 \\
\hline PubMed & 8 & 1 & 2 & 0 & 5 \\
\hline Web of Science & 11 & 1 & 5 & 0 & 5 \\
\hline Scopus & 1 & 0 & 0 & 0 & 1 \\
\hline \multicolumn{5}{|c|}{ Total relevant papers when duplicates removed } & 5 \\
\hline
\end{tabular}

\section{CONFLICT OF INTEREST}

The author declares no conflicts of interest.

\section{REFERENCES}

1. Becskei, C., Cuppens, O., \& Mahabir, S. P. (2018). Efficacy and safety of sarolaner against generalized demodicosis in dogs in European countries: A non-inferiority study. Veterinary Dermatology, 1-

\section{7. https://doi.org/10.1111/vde.12526}


2. Beugnet, F., Halos, L., Larsen, D., \& de Vos, C. (2016). Efficacy of oral afoxolaner for the treatment of canine generalised demodicosis. Parasite, 23, 14. https://doi.org/10.1051/parasite/2016014

3. Fourie, J. J., Liebenberg, J. E., Horak, I. G., Taenzler, J., Heckeroth, A. R., \& Frénais, R. (2015). Efficacy of orally administered fluralaner (Bravecto ${ }^{\circ}$ ) or topically applied imidacloprid/moxidectin (Advocate ${ }^{\circledR}$ ) against generalized demodicosis in dogs. Parasites and Vectors, 8(1), 1-

8. https://doi.org/10.1186/s13071-015-0775-8

4. Fourie, J. J., Meyer, L., \& Thomas, E. (2019). Efficacy of topically administered fluralaner or imidacloprid/moxidectin on dogs with generalised demodicosis. Parasites and Vectors. https://doi.org/10.1186/s13071-018-3230-9

5. Mueller, R. S., Bensignor, E., Ferrer, L., Holm, B., Lemarie, S., Paradis, M., \& Shipstone, M. A. (2012). Treatment of demodicosis in dogs: 2011 clinical practice guidelines. Veterinary Dermatology, 23(2). https://doi.org/10.1111/j.1365-3164.2011.01026.x

6. Perego, R., Spada, E., Foppa, C., \& Proverbio, D. (2019). Critically appraised topic for the most effective and safe treatment for canine generalised demodicosis. BMC Veterinary Research. https://doi.org/10.1186/s12917-018-1767-7

7. Six, R. H., Becskei, C., Mazaleski, M. M., Fourie, J. J., Mahabir, S. P., Myers, M. R., \& Slootmans, N. (2016). Efficacy of sarolaner, a novel oral isoxazoline, against two common mite infestations in dogs: Demodex spp. and Otodectes cynotis. Veterinary Parasitology, 222, 6266. https://doi.org/10.1016/j.vetpar.2016.02.027 


\section{Intellectual Property Rights}

Authors of Knowledge Summaries submitted to RCVS Knowledge for publication will retain copyright in their work, and will be required to grant RCVS Knowledge a non-exclusive license of the rights of copyright in the materials including but not limited to the right to publish, re-

publish, transmit, sell, distribute and otherwise use the materials in all languages and all media throughout the world, and to license or permit others to do so.

\section{Disclaimer}

Knowledge Summaries are a peer-reviewed article type which aims to answer a clinical question based on the best available current evidence. It does not override the responsibility

of the practitioner. Informed decisions should be made by considering such factors as individual clinical expertise and judgement along with patient's circumstances and owners' values. Knowledge Summaries are a resource to help inform and any opinions expressed within the Knowledge Summaries are the author's own and do not necessarily reflect the view of the RCVS Knowledge. Authors are responsible for the accuracy of the content. While the Editor and Publisher believe that all content herein are in accord with current recommendations and practice at the time of publication, they accept no legal responsibility

for any errors or omissions, and make no warranty, express or implied, with respect to material contained within.

For further information please refer to our Terms of Use.

RCVS Knowledge is the independent charity associated with the Royal College of Veterinary Surgeons (RCVS). Our ambition is to become a global intermediary for evidence based veterinary knowledge by providing access to information that is of immediate value to practicing veterinary professionals and directly contributes to evidence based clinical decision-making.

https://www.veterinaryevidence.org/

RCVS Knowledge is a registered Charity No. 230886.

Registered as a Company limited by guarantee in England and Wales No. 598443.

Registered Office: Belgravia House, 62-64 Horseferry Road, London SW1P 2AF

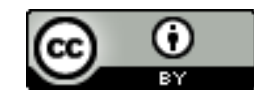

This work is licensed under a Creative Commons Attribution 4.0 International License 